\title{
Adaptable dual control systems for earthquake resistance
}

\author{
M. C. Phocas \& T. L. Sophocleous \\ Department of Architecture, University of Cyprus, Nicosia, Cyprus
}

\begin{abstract}
The use of passive energy dissipation systems for seismic control has been proven internationally over the past years as most promising. The proposed concept of Adaptable Dual Control Systems (ADCS), presented in the present paper, relies on the seismic performance of braced frames with cables or tension only rods, following a closed circuit, and hysteretic dampers. ADCS are based on a dual function of the component members, resulting in two practically uncoupled systems: a primary and a secondary system. The primary frame is responsible for the normal vertical and horizontal forces, while the closed damper-bracing mechanism, for the earthquake forces and the necessary energy dissipation. The bracing members are fixed at the bottom of the columns and are free to move horizontally at the primary frame's joints. Relative displacements are induced between the energy dissipation system's component members and the main frame's members. The potentials for maximum energy dissipation of the proposed systems are investigated in three configurations of the control system. In all cases the damper utilizes the relative displacement between its end joints to yield in the inelastic region, enabling the primary frame to resist elastically. ADCS may result to significant energy dissipation, when all design parameters involved are accordingly predefined. The predominant parameters that characterize ADCS seismic behavior are verified in respect to the mechanical properties of the control elements under the action of ten selected earthquake records of the Greek-Mediterranean region. A comparative parametric analysis of the three systems' seismic behavior leads to significant recommendations for their application as alternative energy dissipation systems.
\end{abstract}

Keywords: earthquake resistance, frame structures, passive control, adaptable systems. 


\section{Introduction}

In most recent developments, buildings are usually stiffened for preventing seismic damage. Bracings add stiffness and damping to the structures, they reduce inter-storey drifts, but they increase floor accelerations. Flexible buildings instead produce under earthquake actions large displacements and small accelerations. The method of adding mechanical devices in frame structures that would passively absorb and dissipate the seismic energy has already proven to be a reliable and effective strategy. A number of energy dissipation devices has been developed and tested since the late 1990s [1, 10]. Such mechanical devices are usually attached to bracings of frames to deform and dissipate energy by different means such as: motion of a piston or a plate within a viscous fluid (viscous dampers), or viscoelastic action in polymeric materials (viscoelastic dampers), sliding friction (friction dampers), or yielding of mild steel (metallic dampers). Whereas the most significant advantage of the method is that the composition leads to a concentration of energy in the specified objective areas and therefore the plastic displacements in regions away from the frame members, some weaknesses of the approach restrain their broad application. High cost, disruptions during construction, heavy members, increase of the primary system's stiffness, residual deformations and minor hysteretic loops are sometimes in this context disadvantageous.

The recent international literature contains three examples of utilizing tendons in frames with the objective to overcome some of the mentioned disadvantages. In the first system the energy dissipation potential of frame structures is effected by the integrated Pall-Marsh modified friction mechanism [6]. The control system consists of an articulated quadrilateral with steel dissipaters, connected through tendons to the frame joints. The second control system consists of eccentrically connected elastic cables and a central energy dissipater working with cyclic bending of steel plates [2] and the third control system, of a friction damping mechanism [3]. All control systems developed concentrate on the optimal design of the section of the damper used through analytical and experimental studies.

In the present study a frame with an integrated hysteretic damper and a cablebracing mechanism in three different configurations is parametrically investigated under actual earthquake motions. The dual structural systems developed are based on the concept originally proposed in [4]. Optimal systems parameters for each configuration of the damper-bracing mechanism have been derived under three international strong earthquake motions, as regards the energy dissipation behaviour of the systems and the dampers non-linear response. The systems have been verified in their earthquake response under ten earthquake motions of the Greek Mediterranean region.

\section{Conceptual design principles of ADCS}

An Adaptable Dual Control Mechanism may be developed when tension-only bracings and a hysteretic damper are integrated within a frame to provide 
specific safety for strong earthquake hits. The control members form a kinetically closed circuit and participate in the energy dissipation process in a stable manner for a large number of strong excitation cycles, without any coupling effect with the elastic primary structure; gravity and wind loads are managed by the primary frame, whereas the earthquake loads, by the integrated damper-bracing mechanism.
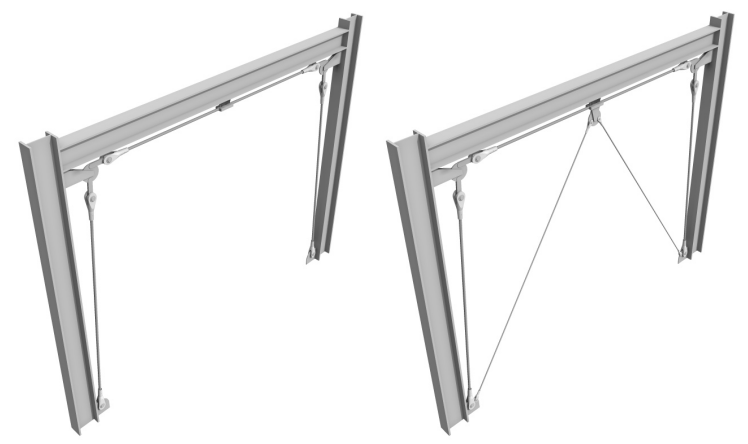

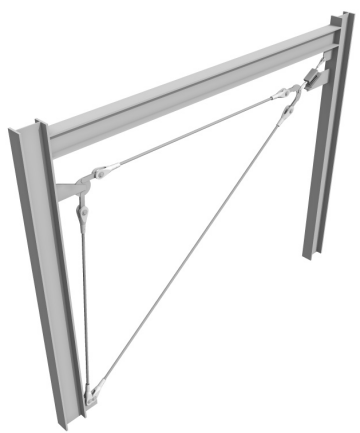

Figure 1: $\quad$ ADCS S1, S2, S3.

The conceptual design principles are mastered by the dual property that generates the form of the systems, whereas the bracing members form a closed polygon shape, fig. 1. Ideally, the reactions from the added control device on the primary frame are almost neutralized due to the closed circuit of the bracing, i.e. the elongation of a bracing cable in one sense is equal in magnitude to the contraction of the other cable that follows the opposite sense, fig. 2.

The design objective of all ADCS configurations is based on achieving predefined performance levels of damage control, through the property of deformation. When the dual mechanism is subjected to earthquake loads, eccentrically placed discs at the main joint regions rotate and drag along the pretensioned bracing cables that induce relative deformations to the integrated hysteretic damper connected to a respective frames member, fig. 3. As soon as the motion between the dampers connection points takes place, dissipation of the seismic input energy initiates. Energy is concentrated on the fusers instead of on the primary system.

\section{Connections design of ADCS}

The ability of mild steel to dissipate energy through inelastic deformations is utilized in the proposed control systems in three examples of ADCS configurations [11]. The optimal position of the hysteretic damper is carefully selected so that it controls the seismic response most effectively, fig. 4. In all cases the parallel steel plates are connected with a cable bracing and a frames 

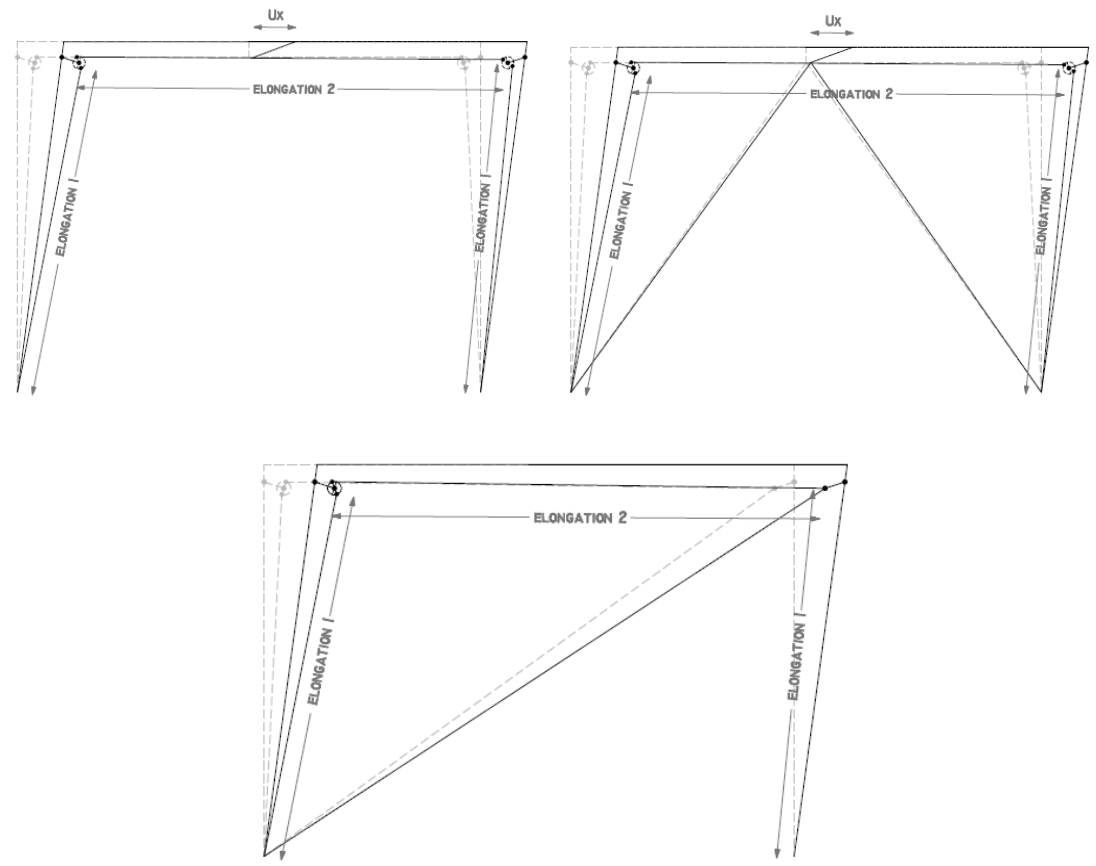

Figure 2: $\quad$ Kinematics of ADCS S1, S2, S3.

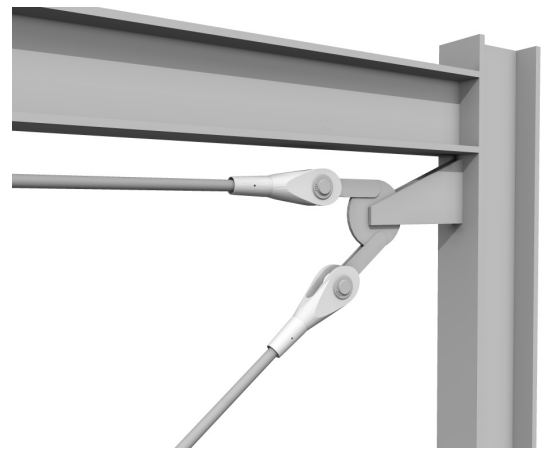

Figure 3: Typical rotating disc at the main joint region of ADCS.

member. The bending curvature that develops by the transverse force applied at the end joints of each triangular plate is uniform over the section's full height. All lines reach their maximum yielding potential at the same time. 

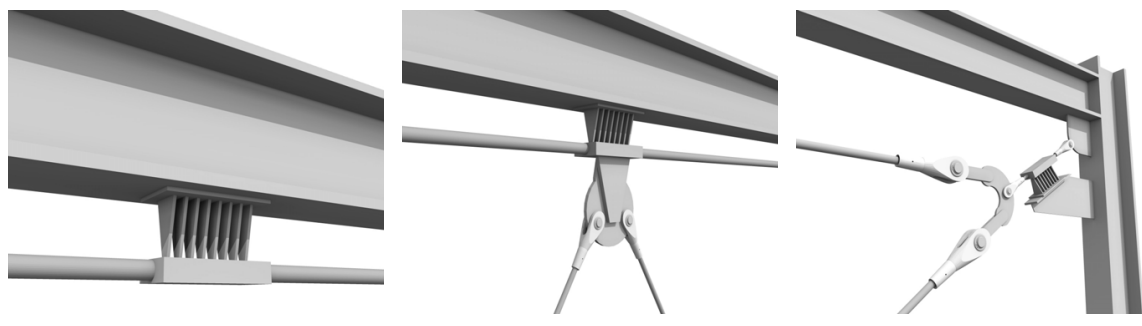

Figure 4: $\quad$ Hysteretic dampers connections of ADCS S1, S2 and S3.

\section{Preliminary design of ADCS}

A typical geometry was assigned for the primary frame for a preliminary study of ADCS's response behavior. The primary frame was dimensioned to resist a vertical load of $\mathrm{G}=1200 \mathrm{kN}$, a horizontal wind load of $\mathrm{W}=15 \mathrm{kN}$ and a minimum of $25 \%$ of the static equivalent seismic loads. According to Eurocode 3 an IPBL500 section was assigned for the $4.50 \mathrm{~m}$ high columns and an IPBL550 section for the $6.00 \mathrm{~m}$ long beam (S235, $\left.\mathrm{E}=2.1 \times 10^{4} \mathrm{kN} / \mathrm{cm}^{2}, \rho=78.5 \mathrm{kN} / \mathrm{m}^{3}\right)$. Furthermore $0 \%$ damping was assumed for the dynamic loading.

\subsection{Hysteretic behaviour of bracing-damper mechanism}

The optimization method implies the selection of the maximum deformation and yield strength for the selected damper plates under the indicated hysteretic behavior modeled by the Bouc-Wen plasticity model of hysteresis. Three characteristic parameters were found to control the response: the device initial elastic stiffness, $\mathrm{k}_{\mathrm{d}}$, the device yield force, $\mathrm{P}_{\mathrm{y}}$, and the tendon bracings' elastic stiffness. The former are given through the following equations:

$$
\begin{aligned}
& \mathrm{k}_{\mathrm{d}}=\frac{\mathrm{nEbt}^{3}}{4 \mathrm{~h}^{3}}, \\
& \mathrm{P}_{\mathrm{y}}=\frac{\mathrm{nf}_{\mathrm{y}} \mathrm{bt}^{2}}{6 \mathrm{~h}}
\end{aligned}
$$

The geometry of the dissipaters, as triangular shaped plates, is characterized by the height, $h$, the width, $b$, the thickness, $t$, and the number of plates, $n . f_{y}$ is the yield stress (for the material chosen, $\mathrm{S} 235, \mathrm{f}_{\mathrm{y}}=24 \mathrm{kN} / \mathrm{cm}^{2}, \rho=78.5 \mathrm{kN} / \mathrm{m}^{3}$ ) and $\mathrm{E}$ is the modulus of Elasticity $\left(\mathrm{E}=2.1 \times 10^{4} \mathrm{kN} / \mathrm{cm}^{2}\right)$. The tendons' elastic stiffness was selected based on the study results as described in previous investigations by the authors [4, 5, 7-9].

\subsection{Design variables for ADCS}

A parametric analysis has been conducted by varying the members' stiffness and yield strength. In the present study all tendons have diameter of $\mathrm{dc}=20 \mathrm{~mm}$ and 
modulus of elasticity of $\mathrm{E}=1.6 \times 10^{4} \mathrm{kN} / \mathrm{cm}^{2}$. The bracing configurations of the systems enable that the damper plates yield before any other member of the system. The sensitivity study verified that the ADCS's behavior is mainly governed by the hysteresis of the incorporated damper, i.e. the eligible stiffness and ductility levels, that is responsible for the respective energy dissipation and the relative motion between the damper's end joints defined as interdamper drift. The derived diagrams may be used to define the targeted energy dissipation, through the selection of a single Energy Toughness Indicator value, i.e. dissipated- to input energy, which is presented as a variation of a DR parameter, defined as the damper's elastic stiffness, $\mathrm{kd}$, to its yield force, Py. The proposed ADCS were subjected to real records of international strong earthquakes that are characterised by peak ground acceleration values of $0.810 \mathrm{~g}, 0.604 \mathrm{~g}$ and $0.348 \mathrm{~g}$. The preliminary investigation has been conducted for the three selected configurations of the ADCS systems and for an arbitrary sample of possible combinations of design parameter values. The optimal design parameters DR of the systems have been derived based on the sensitivity study results for 342 combinations for S1 and S3 and 397 for S2. Subsequently ADCS have been evaluated in their dynamic behaviour under ten selected earthquake excitations of the Greek-Mediterranean region.

\subsection{Energy toughness indicator}

Based on the parametric investigation results as shown in fig. 5 for the three systems, the critical parameter is the non-linear link parameter DR, defined as the damper's stiffness to its yield strength. This parameter influences to a high degree the area of the dissipated energy through the yielding deformations of the hysteretic damper, as a portion of the input energy, for the earthquake cases with maximum ground acceleration PGA of $0.348 \mathrm{~g}, 0.604 \mathrm{~g}$ and $0.810 \mathrm{~g}$. As indicated in the individual diagrams, the favourable design parameter for all combinations lies between the areas of $100<\mathrm{DR}<200$.

\section{Earthquake response of ADCS}

A selection of favourable ADCS responses with the selected DR parameter under the earthquake excitations of the Greek-Mediterranean region is shown in fig. 6 . In the analysis the steel dampers dissipated a major part of the earthquake input energy, in dependence to the characteristics of the ground motions. The form of the hysteretic loops developed depends primarily on the grade of the plastic hysteretic damping. The hysteretic damper in the system S1 develops exclusively hysteresis curves, similar to the Ramberg-Osgood model. The systems S2 and S3 develop in most cases hysteresis curves of the rigid-plastic type model. 

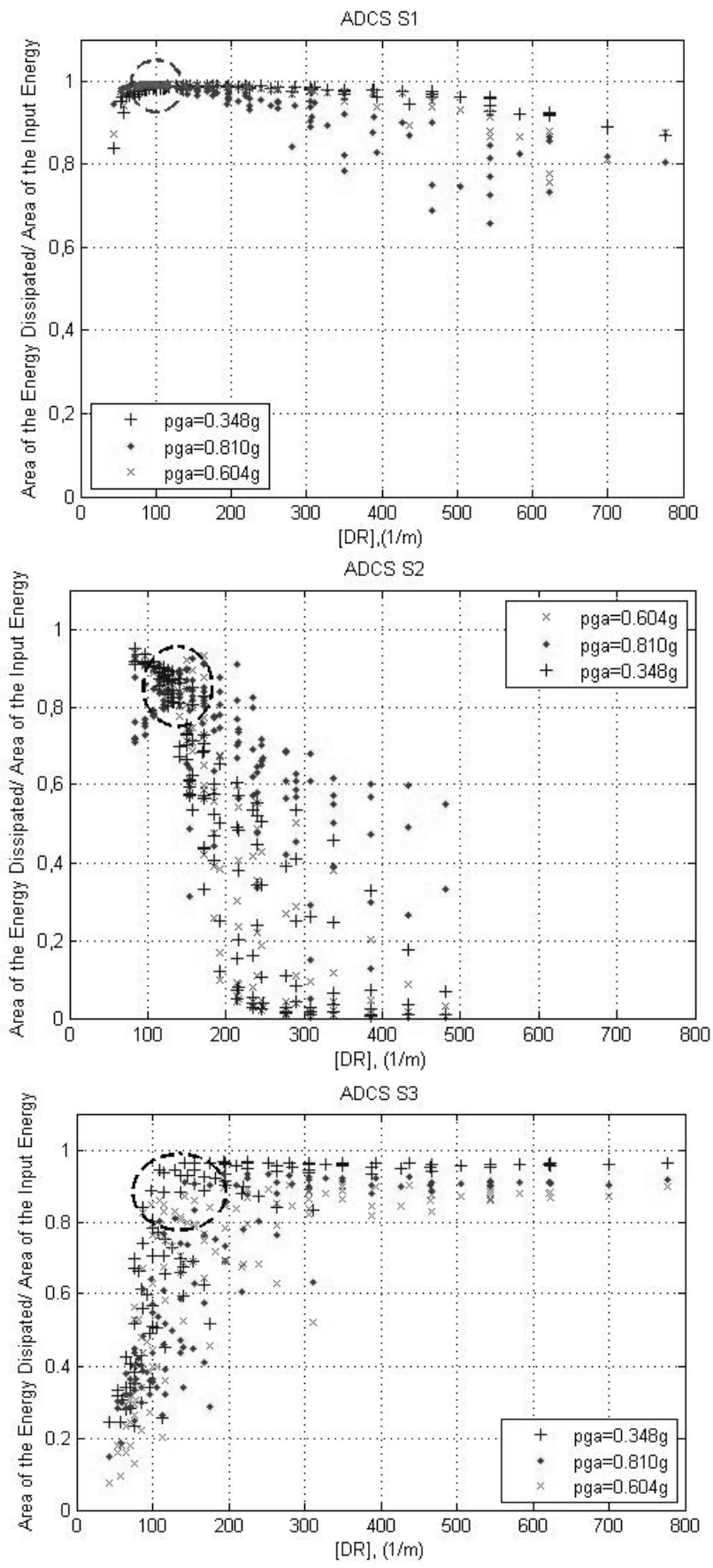

Figure 5: $\quad$ DR Parameters of ADCS S1, S2 and S3. 

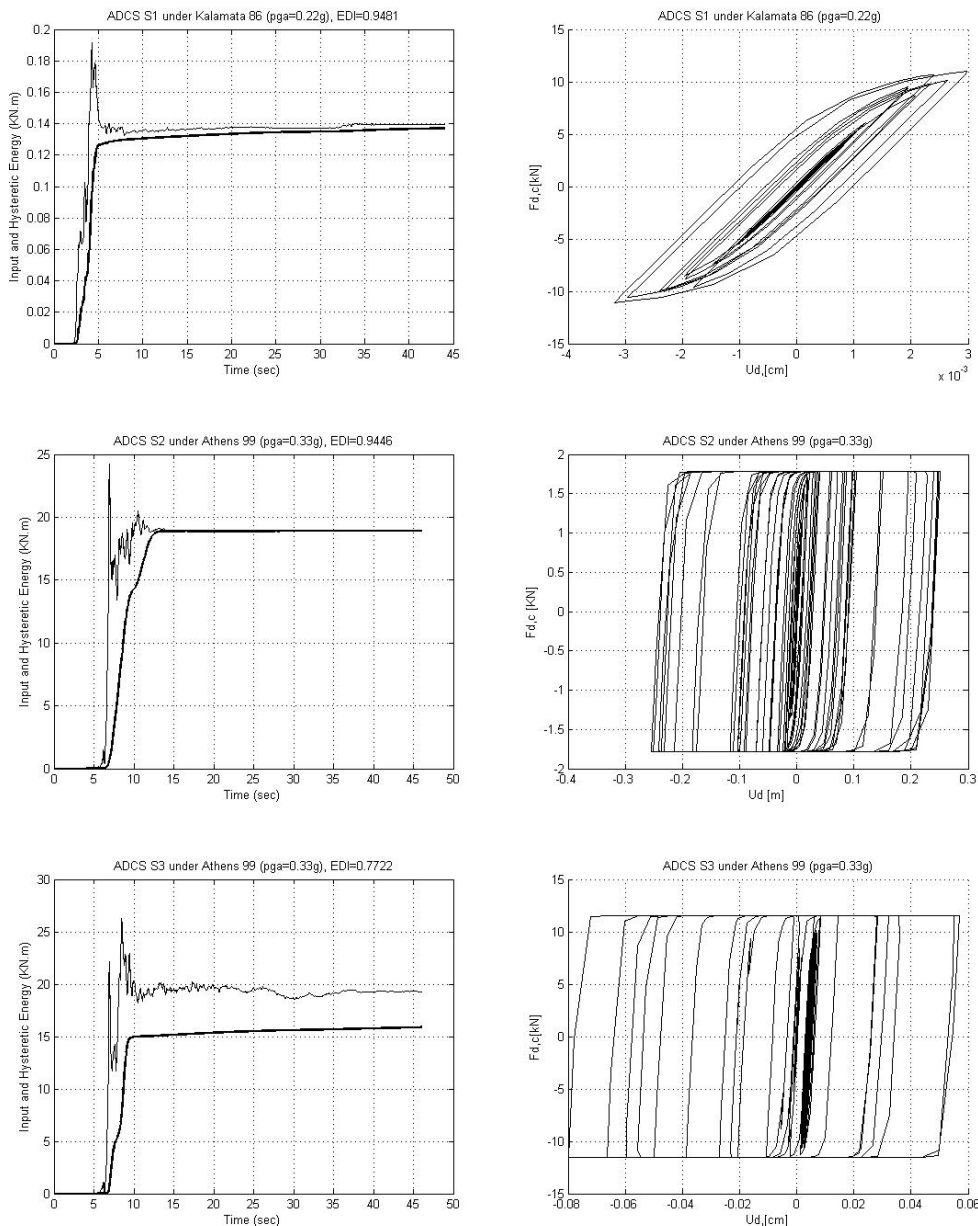

Figure 6: Favourable energy dissipation- and hysteretic behaviour of ADCS $\mathrm{S} 1, \mathrm{~S} 2$ and $\mathrm{S} 3$.

\subsection{Base shear}

The comparison of the base shear's maximum values of S1, S2 and S3 with the bare frame's values proves that the secondary damper-bracing mechanism does not practically induce any coupling effects to the systems. The favourable case presented in Table 1, is characterized by the following geometry of the plate fusers: $\mathrm{h}=15 \mathrm{~cm}, \mathrm{~b}=5 \mathrm{~cm}, \mathrm{t}=12 \mathrm{~mm}$ and $\mathrm{n}=6$. In $83.33 \%$ of the cases the base shear decreased, when the tendons and the hysteretic steel plates were added to the frame system. 
Table 1: $\quad$ Base shear of bare frame and ADCS S1, S2, S3.

\begin{tabular}{|c|c|c|c|c|}
\hline Earthquake Records & \multicolumn{4}{|c|}{ Base Shear $(\mathrm{kN})$} \\
\hline $\begin{array}{l}\text { Max. Ground } \\
\text { Acceleration }\end{array}$ & $\begin{array}{c}\text { Bare } \\
\text { Frame } \\
(\mathrm{T}=0.36 \mathrm{~s})\end{array}$ & $\begin{array}{l}\text { ADCS S1 } \\
(\mathrm{T}=0.32 \mathrm{~s})\end{array}$ & $\begin{array}{l}\text { ADCS S2 } \\
(\mathrm{T}=0.26 \mathrm{~s})\end{array}$ & $\begin{array}{l}\text { ADCS S3 } \\
(\mathrm{T}=0.67 \mathrm{~s})\end{array}$ \\
\hline $\begin{array}{c}\text { Aigio } 95\left(\text { Aigio, } 0^{0}\right) \\
0.50 \mathrm{~g}\end{array}$ & $\begin{array}{c}-1563.00 \\
1577.00\end{array}$ & $\begin{array}{l}-63.76 \\
40.49\end{array}$ & $\begin{array}{c}-3048.43 \\
3057.49\end{array}$ & $\begin{array}{c}-1184.98 \\
1225.26\end{array}$ \\
\hline $\begin{array}{c}\text { Athens } 99\left(\text { Sepolia, } 0^{0}\right) \text {, } \\
0.33 \mathrm{~g}\end{array}$ & $\begin{array}{c}-2048.00 \\
1978.00\end{array}$ & $\begin{array}{l}-34.22 \\
29.04\end{array}$ & $\begin{array}{r}-1176.91 \\
1101.54\end{array}$ & $\begin{array}{c}-1761.55 \\
1611.12\end{array}$ \\
\hline $\begin{array}{c}\text { Ionian } 83 \text { (Argostoli, } \\
\left.90^{\circ}\right), 0.24 \mathrm{~g}\end{array}$ & $\begin{array}{c}-500.30 \\
480.40\end{array}$ & $\begin{array}{c}-25.54 \\
17.98\end{array}$ & $\begin{array}{c}-324.24 \\
379.65\end{array}$ & $\begin{array}{c}-546.00 \\
545.53\end{array}$ \\
\hline $\begin{array}{c}\text { Kalamata } 86 \text { (Kalamata, } \\
\left.0^{0}\right), 0.22 \mathrm{~g}\end{array}$ & $\begin{array}{c}-1278.00 \\
1270.00\end{array}$ & $\begin{array}{c}-28.04 \\
30.24\end{array}$ & $\begin{array}{c}-1874.30 \\
1883.07\end{array}$ & $\begin{array}{c}-256.62 \\
300.45\end{array}$ \\
\hline $\begin{array}{c}\text { Heraklio } 84 \text { (Heraklio, } \\
\left.90^{\circ}\right), 0.21 \mathrm{~g}\end{array}$ & $\begin{array}{c}-1738.00 \\
1735.00\end{array}$ & $\begin{array}{l}-15.70 \\
23.42\end{array}$ & $\begin{array}{l}-1517.44 \\
1516.73\end{array}$ & $\begin{array}{c}-882.94 \\
861.29\end{array}$ \\
\hline $\begin{array}{c}\text { Aigio } 90\left(\text { Aigio, } 90^{\circ}\right), \\
0.20 \mathrm{~g}\end{array}$ & $\begin{array}{c}-1361.00 \\
1361.00\end{array}$ & $\begin{array}{l}-21.55 \\
20.32\end{array}$ & $\begin{array}{c}-665.95 \\
593.36\end{array}$ & $\begin{array}{c}-1191.58 \\
1220.42\end{array}$ \\
\hline $\begin{array}{c}\text { Etolia } 88 \text { (Valsamata, } \\
\left.90^{\circ}\right), 0.18 \mathrm{~g}\end{array}$ & $\begin{array}{l}-882.90 \\
848.40\end{array}$ & $\begin{array}{l}-15.83 \\
20.79\end{array}$ & $\begin{array}{c}-1358.78 \\
1308.86\end{array}$ & $\begin{array}{l}-1153.24 \\
1182.53\end{array}$ \\
\hline $\begin{array}{c}\text { Killini } 88 \text { (Zakinthos, } \\
\left.90^{\circ}\right), 0.15 \mathrm{~g}\end{array}$ & $\begin{array}{c}-2515.00 \\
2516.00\end{array}$ & $\begin{array}{c}-16.99 \\
20.79\end{array}$ & $\begin{array}{c}-525.65 \\
561.32\end{array}$ & $\begin{array}{c}-1193.32 \\
1212.84\end{array}$ \\
\hline $\begin{array}{c}\text { Preveza } 81 \text { (Preveza, } \\
\left.0^{0}\right), 0.14 \mathrm{~g}\end{array}$ & $\begin{array}{c}-2445.00 \\
2381.00\end{array}$ & $\begin{array}{c}-16.36 \\
15.26\end{array}$ & $\begin{array}{c}-1119.47 \\
1168.68\end{array}$ & $\begin{array}{r}-1551.07 \\
1570.20\end{array}$ \\
\hline $\begin{array}{c}\text { Gulf of Corinth } 93 \\
\left(\text { Nafpaltos, } 90^{\circ}\right), 0.10 \mathrm{~g}\end{array}$ & $\begin{array}{l}-372.80 \\
519.10\end{array}$ & $\begin{array}{l}-12.93 \\
20.32\end{array}$ & $\begin{array}{l}-316.91 \\
248.97\end{array}$ & $\begin{array}{c}-356.06 \\
517.56\end{array}$ \\
\hline
\end{tabular}

\subsection{Relative horizontal displacement}

For the same geometry assigned to the damper, the relative displacement of S1, $\mathrm{S} 2$ and $\mathrm{S} 3$ is compared to the bare frame's values. In $93.33 \%$ of the cases examined the response values are kept within the frame's limits. This is also valid for the case presented in Table 2.

\subsection{Interdamper drift}

Responsible for the energy dissipation of the systems is the inelastic action induced between the damper's end point joints, defined as interdamper drift. The one end of the damper follows the axial displacement of the connected tendon and the other end the frame's member translation. The damper utilizes the relative motion to yield and dissipate energy. Fig. 7 shows the relative 
Table 2: $\quad$ Relative displacement.

\begin{tabular}{|c|c|c|c|c|}
\hline Earthquake Records & \multicolumn{4}{|c|}{ Relative Displacement (cm) } \\
\hline $\begin{array}{l}\text { Max. Ground } \\
\text { Acceleration }\end{array}$ & $\begin{array}{l}\text { Bare Frame } \\
(\mathrm{T}=0.36 \mathrm{~s})\end{array}$ & $\begin{array}{c}\text { ADCS S1 } \\
(\mathrm{T}=0.32 \mathrm{~s})\end{array}$ & $\begin{array}{c}\text { ADCS S2 } \\
(\mathrm{T}=0.26 \mathrm{~s})\end{array}$ & $\begin{array}{c}\text { ADCS S3 } \\
(\mathrm{T}=0.67 \mathrm{~s})\end{array}$ \\
\hline $\begin{array}{c}\text { Aigio } 95\left(\text { Aigio, } 0^{0}\right), \\
0.50 \mathrm{~g}\end{array}$ & $\begin{array}{c}1.918 \\
-1.899 \\
\end{array}$ & $\begin{array}{r}0.010 \\
-0.011 \\
\end{array}$ & $\begin{array}{r}1.918 \\
-1.912 \\
\end{array}$ & $\begin{array}{r}1.560 \\
-1.620 \\
\end{array}$ \\
\hline $\begin{array}{c}\text { Athens } 99\left(\text { Sepolia, } 0^{0}\right) \text {, } \\
0.33 \mathrm{~g}\end{array}$ & $\begin{array}{c}2.494 \\
-2.417\end{array}$ & $\begin{array}{c}0.011 \\
-0.009\end{array}$ & $\begin{array}{r}2.498 \\
-2.409\end{array}$ & $\begin{array}{c}2.330 \\
-2.150\end{array}$ \\
\hline $\begin{array}{c}\text { Ionian } 83 \text { (Argostoli, } \\
\left.90^{\circ}\right), 0.24 \mathrm{~g}\end{array}$ & $\begin{array}{c}0.633 \\
-0.587 \\
\end{array}$ & $\begin{array}{c}0.003 \\
-0.003 \\
\end{array}$ & $\begin{array}{c}0.614 \\
-0.594 \\
\end{array}$ & $\begin{array}{c}0.750 \\
-0.710 \\
\end{array}$ \\
\hline $\begin{array}{c}\text { Kalamata } 86 \text { (Kalamata, } \\
\left.0^{0}\right), 0.22 \mathrm{~g}\end{array}$ & $\begin{array}{c}1.542 \\
-1.533\end{array}$ & $\begin{array}{c}0.013 \\
-0.012\end{array}$ & $\begin{array}{r}1.533 \\
-1.505\end{array}$ & $\begin{array}{c}0.340 \\
-0.400\end{array}$ \\
\hline $\begin{array}{c}\text { Heraklio } 84 \text { (Heraklio, } \\
\left.90^{\circ}\right), 0.21 \mathrm{~g}\end{array}$ & $\begin{array}{c}2.119 \\
-2.113\end{array}$ & $\begin{array}{c}0.006 \\
-0.006\end{array}$ & $\begin{array}{c}1.702 \\
-1.716\end{array}$ & $\begin{array}{c}1.160 \\
-1.130\end{array}$ \\
\hline $\begin{array}{c}\text { Aigio } 90\left(\text { Aigio, } 90^{\circ}\right) \\
0.20 \mathrm{~g}\end{array}$ & $\begin{array}{c}1.661 \\
-1.660\end{array}$ & $\begin{array}{c}0.006 \\
-0.005\end{array}$ & $\begin{array}{r}1.530 \\
-1.599\end{array}$ & $\begin{array}{c}1.570 \\
-1.600\end{array}$ \\
\hline $\begin{array}{c}\text { Etolia } 88 \text { (Valsamata, } \\
\left.90^{0}\right), 0.18 \mathrm{~g}\end{array}$ & $\begin{array}{c}1.067 \\
-1.038\end{array}$ & $\begin{array}{c}0.009 \\
-0.008\end{array}$ & $\begin{array}{r}1.044 \\
-0.991\end{array}$ & $\begin{array}{c}1.520 \\
-1.560\end{array}$ \\
\hline $\begin{array}{c}\text { Killini } 88 \text { (Zakinthos, } \\
\left.90^{\circ}\right), 0.15 \mathrm{~g}\end{array}$ & $\begin{array}{r}3.066 \\
-3.065\end{array}$ & $\begin{array}{c}0.005 \\
-0.005\end{array}$ & $\begin{array}{c}2.418 \\
-2.459\end{array}$ & $\begin{array}{l}1.570 \\
-1.60\end{array}$ \\
\hline $\begin{array}{c}\text { Preveza } 81 \text { (Preveza, } \\
\left.0^{0}\right), 0.14 \mathrm{~g}\end{array}$ & $\begin{array}{r}2.977 \\
-2.897\end{array}$ & $\begin{array}{c}0.008 \\
-0.007\end{array}$ & $\begin{array}{r}2.730 \\
-2.647\end{array}$ & $\begin{array}{c}2.080 \\
-2.100\end{array}$ \\
\hline $\begin{array}{c}\text { Gulf of Corinth } 93 \\
\left.\text { (Nafpaltos, } 90^{\circ}\right), 0.10 \mathrm{~g}\end{array}$ & $\begin{array}{c}0.463 \\
-0.629\end{array}$ & $\begin{array}{c}0.004 \\
-0.004\end{array}$ & $\begin{array}{c}0.460 \\
-0.624\end{array}$ & $\begin{array}{c}0.470 \\
-0.680\end{array}$ \\
\hline
\end{tabular}

displacements response of S1, S2 and S3 respectively. It can be observed that the relative deformations of the damper are proportional to the energy dissipation of the control mechanism. Therefore the maximization of the interdamper drift is a design objective for ADCS.

\section{Conclusions}

In the present paper the concept of Adaptable Dual Control Systems is analytically investigated in three different configurations. The proposed systems consist of a hysteretic damper and a cable bracing mechanism of closed circuit that are integrated within the frame structure to dissipate satisfactory portions of the seismic input energy, leaving the primary frame to respond elastically. The unique configuration of the tendons avoids the undesirable effect from a possible increase in the base shear and it keeps the relative displacements of the systems under controllable limits. The systems have been investigated in their response, based on a parametric study using three international strong earthquake motions. The analyses conducted revealed the design parameters of the control mechanisms and the range of ADCS's possible applications. The ADCS's reliability was verified as regards their earthquake performance under ten real earthquake records of the Greek Mediterranean region. 

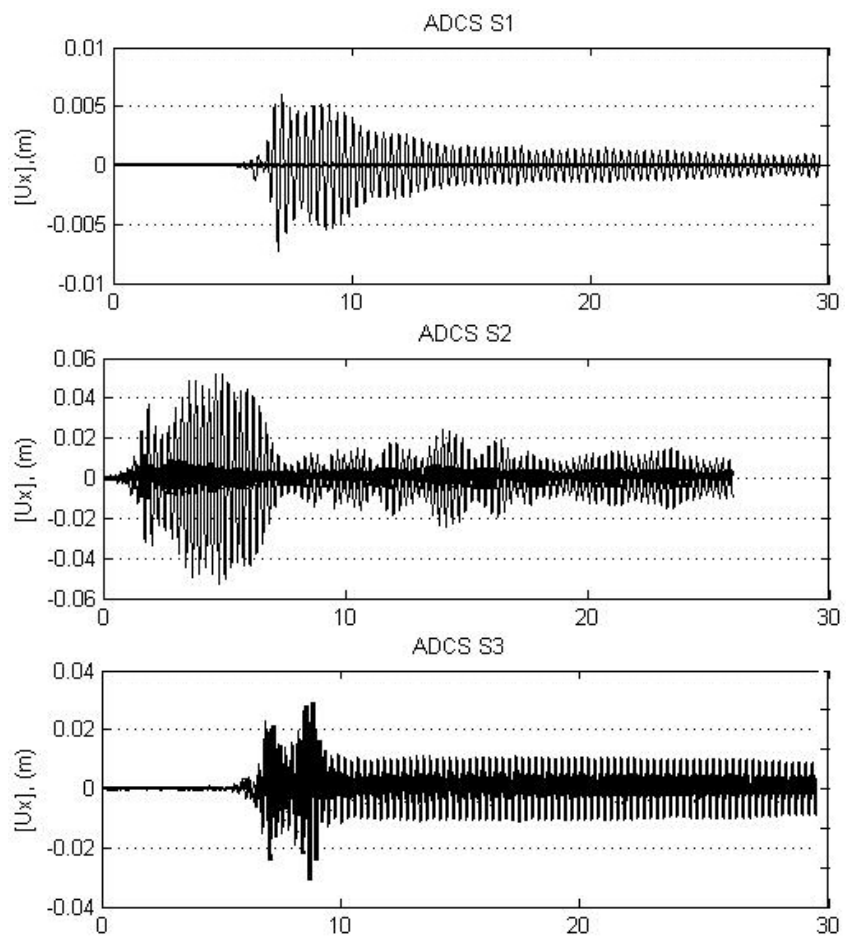

Figure 7: $\quad$ Interdamper drift in ADCS S1, S2 and S3.

\section{References}

[1] Housner, G.W., Bergman, L.A., Caughey, T.K., Chassiakos, A.G., Claus, R.O., Masri, S.F., Skelton, R.E., Soong, T.T., Spencer, Jr. B.F. \& Yao, T.P., Structural Controls: Past, Present and Future. Engineering Mechanics, 123(9), pp. 897-971, 1997.

[2] Kurata, M., DesRoches, R. \& Leon, R.T., Cable Damper Bracing for Partial Seismic Rehabilitation. 14th World Conference on Earthquake Engineering, 14WCEE, 12.10-17.10.08: Beijing, China, October 2008.

[3] Mualla, I.H., Nielsen, L.O., Belev, B., Liao, W.I., Loh, C.H. \& Agrawal, A., Performance of Friction-Damped Frame Structure: Shaking Table Testing and Numerical Simulations. 7th US National Conference on Earthquake Engineering: Boston, USA, 2002.

[4] Phocas, M.C. \& Pocanschi, A., Steel Frames with Bracing Mechanism and Hysteretic Dampers. Earthquake Engineering and Structural Dynamics, 32, pp. 811-825, 2003.

[5] Phocas, M.C. \& Sophocleous, T., Kinetic Structures in Architecture.14th World Conference on Earthquake Engineering, 14WCEE, 12.10-17.10.08: Beijing, China, October 2008. 
[6] Renzi, E., Perno, S., Pantanella, S. \& Ciampi, V., Design, Test and Analysis of a Light-Weight Dissipative Bracing System for Seismic Protection of Structures. Earthquake Engineering and Structural Dynamics, 36, pp. 519-539, 2007.

[7] Sophocleous, T. \& Phocas, M.C., Dual Earthquake Resistant Frames. (eds.), Earthquake Resistant Engineering Structures VII, eds. Phocas, M., Brebbia, C.A., Komodromos, P., WIT Press: Southampton, pp. 165-174, 2009.

[8] Sophocleous, T. \& Phocas, M.C., Dual Structures Towards Kinetic Adaptability for Earthquake Resistance. First International Conference on Structures \& Architecture, ICSA2010, 21.07 - 23.07.10: Guimaraes, Portugal, July 2010.

[9] Sophocleous, T. \& Phocas, M.C., Model of Analysis for Earthquake Resistant Dual Systems. 2nd International Conference on Computational Methods in Structural Dynamics and Earthquake Engineering, COMPDYN 2009, 22.06-24.06.09: Rhodes, Greece, June 2009.

[10] Symans. M.D., Charney, F., Constantinou, M.C., Kircher, C., Johnson, M.W. \& McNamara, R.J. Energy Dissipation Systems for Seismic Applications: Current Practice and Recent Developments. Structural Engineering, 134(1), pp. 3-21, 2008.

[11] Tsai, K.C., Chen, H.W., Hong, C.P. \& Su, Y.F., Design of Steel Triangular Plate Energy Absorbers for Seismic-Resistance Construction. Earthquake spectra, 9, pp. 505-528, 1993. 